\title{
The Profile of Students' Critical Thinking Ability in in X IPA SMA Negeri 7 Cirebon
}

\author{
$1^{\text {st }}$ Sugeng Riyadi \\ Science Education, Postgraduate \\ Program \\ Sebelas Maret University (UNS) \\ Surakarta, Indonesia \\ riyadisugeng419@gmail.com
}

\author{
$2^{\text {nd }}$ Sarwanto \\ Science Education, Postgraduate \\ Program \\ Sebelas Maret University (UNS) \\ Surakarta, Indonesia \\ sarwanto@fkip.uns.ac.id
}

\author{
$3^{\text {rd }}$ Yudi Rinanto \\ Science Education, Postgraduate \\ Program \\ Sebelas Maret University (UNS) \\ Surakarta, Indonesia \\ yudi.rinanto@staff.uns.ac.id
}

\begin{abstract}
The ability to think critically is very important to develop thinking in solving problems. Critical thinking and problem solving are considered to be a new basis for 21 st century learning. The research objective is to analyze students' critical thinking skills. The research design uses quantitative descriptive method. The study was conducted on students of class X IPA at SMAN 7 Cirebon in the 2018/2019 school year which was determined by cluster random sampling. The instrument used is a test question in the form of a description developed based on indicators of critical thinking skills. Data analysis is carried out in quantitative percentages. Based on the results of data analysis, the average students' critical thinking skills were $49.57 \%$ in the very low category. The percentage on the indicator identifies or formulates the problem by $44 \%$ in the very low category, the indicator identifies or formulates the criteria to determine an important answer by $51 \%$ in the very low category, indicators for building basic skills by $59 \%$ in the low category, the indicator concludes at $54 \%$ in very low category, indicators induce and consider the results of induction by $50 \%$ in the very low category, indicators provide further explanations by $38 \%$ in the very low category and indicators compile strategies and tactics by $51 \%$ in the very low category. The results of this study provide information about the profile of critical thinking skills of students at SMA Negeri 7 Cirebon is still very low.
\end{abstract}

\section{Keywords-Ability, Critical Thinking, SMAN 7 Cirebon}

\section{INTRODUCTION}

At present, education is in a knowledge age with an extraordinary increase in knowledge. The acceleration of increased knowledge is supported by the application of digital media and technology called the information super highway [1] The skills that must be possessed by the 21 st century are in the form of life and career skills, learning and innovation skills and information media and technology skills [2].

Critical thinking skills are important to prepare students or students to face technological changes that are so fast to anticipate the decline of thinking in the digital world [3]. The application of critical thinking through a framework that requires commitment to active learning, student-centered, although initially learning is less desirable and inconvenient between students and teachers [4]. Critical thinking is a general term given to the various cognitive skills and intellectual dispositions needed to identify, analyze and evaluate arguments and truths and to find and overcome personal prejudices and irregularities in formulating and providing compelling reasons to support conclusions and make reasonable decisions and smart about what to believe and what to do [5].

Critical thinking is the process of intellectual discipline that actively and skillfully conceptualizes, implements, analyzes, synthesizes, and evaluates information gathered or results from observation, experience, reflection, reasoning or communication as a guide to beliefs and actions [6]. Through critical thinking, students can be taught to critically examine different perspectives on issues related to the impact of science and technology on daily life and evaluate these issues from the perspective of society and the environment. The encouragement of knowledge by educators to students in critical thinking about science and technology, will help develop analysis, skills and the ability to make choices based on information in everyday life [7].

According to Facione (2011) critical thinking consists of six aspects of indicators, namely interpretation, analysis, evaluation, conclusion, explanation and self-regulation [8]. Develop students' critical thinking skills depending on the frequency of activities and exercises because each student has different critical thinking skills [9].

The spirit of students is more likely to be theoretical and less able to develop critical thinking. The spirit of students in answering questions from teachers is more inclined to book writing and has not shown the development of potential and ability in solving problems. Students are still not able to make decisions correctly and relevant or in accordance with existing problems. Based on the background, this study aims to find out the profile of critical thinking skills in grade $\mathrm{X}$ IPA students of SMA Negeri 7 Cirebon. 


\section{METHODS}

The research design uses quantitative descriptive method, namely research refers to the actual conditions in the field by searching and analyzing data. The data sought and analyzed are students' critical thinking skills in Biology learning. Descriptive research describes or illustrates what is happening [10], does not make a comparison of variables with other variables [11]. The research was carried out in SMA Negeri 7 Cirebon. The research sample was 34 students of class X IPA 2018/2019 amounting to 34 students who were determined by cluster random sampling. The instrument used is a description test of critical thinking skills. Data analysis was carried out with quantitative percentage analysis.

As for scoring each indicator of critical thinking ability, each item that represents the indicator is given a score range of $0-4$. Then the score is calculated quantitatively, the score obtained is divided by the maximum score multiplied by one hundred percent. Descriptive percentage formulas are as follows:

\section{Score per indicator $=\frac{\text { Amount of Score Achievement }}{\text { Maximum Score Total }} \times 100 \%$}

The results of the percentage of critical thinking skills are then analyzed based on the categories of percentage of critical thinking skills as follows:

Table 1 Critical Thinking Ability Categories based on percentages

\begin{tabular}{cc}
\hline Percentage Scale & Category \\
\hline $86 \%-100 \%$ & Very good \\
$76 \%-85 \%$ & Good \\
$60 \%-75 \%$ & Enough \\
$55 \%-59 \%$ & Less/Low \\
$<54 \%$ & Very Less/Very Low \\
\hline
\end{tabular}

After being analyzed using quantitative percentage techniques then the data is explained and concluded.

\section{RESULT AND DISCUSSION}

Critical thinking is one of the highest stages of thinking. Students' critical thinking ability is needed in the learning process to create a high curiosity so that students will continue to seek information and think about how to solve the problems they face. Critical thinking is needed to check the truth of the information so that it can be decided that the information is worthy of being rejected or [12].

Critical thinking ability that is measured in research refers to 7 indicators, namely 1) identifying or formulating problems, 2) identifying or formulating criteria to determine important answers, 3) building basic skills, 4) concluding, 5) inducing and considering the results of induction , 6) provide further explanation, 7) develop strategies and tactics.

The question of critical thinking skills that was tested by students was seven questions which were given to 34 students of class X IPA with a duration of 90 minutes. The test results obtained data in the form of student work results which were then analyzed by researchers. The results of the critical thinking ability test are presented in table 2 .

Table 2. Results of Critical Thinking Ability

\begin{tabular}{|c|c|c|}
\hline No & $\begin{array}{c}\text { Indicator of Critical Thinking } \\
\text { Ability }\end{array}$ & $\begin{array}{c}\text { Percentage } \\
\text { of } \\
\text { Achievement } \\
(\%)\end{array}$ \\
\hline 1 & Identify or formulate problems & 44 \\
\hline 2 & $\begin{array}{l}\text { Identify or formulate criteria to } \\
\text { determine important answers }\end{array}$ & 51 \\
\hline 3 & Building basic skills & 59 \\
\hline 4 & Conclude & 54 \\
\hline 5 & $\begin{array}{l}\text { Inducing and considering the } \\
\text { results of induction }\end{array}$ & 50 \\
\hline 6 & Provide further explanation & 38 \\
\hline \multirow[t]{2}{*}{7} & Develop strategies and tactics & 51 \\
\hline & Average & 49.57 \\
\hline
\end{tabular}

Based on table 2, we can graph the critical thinking abilities as follows:

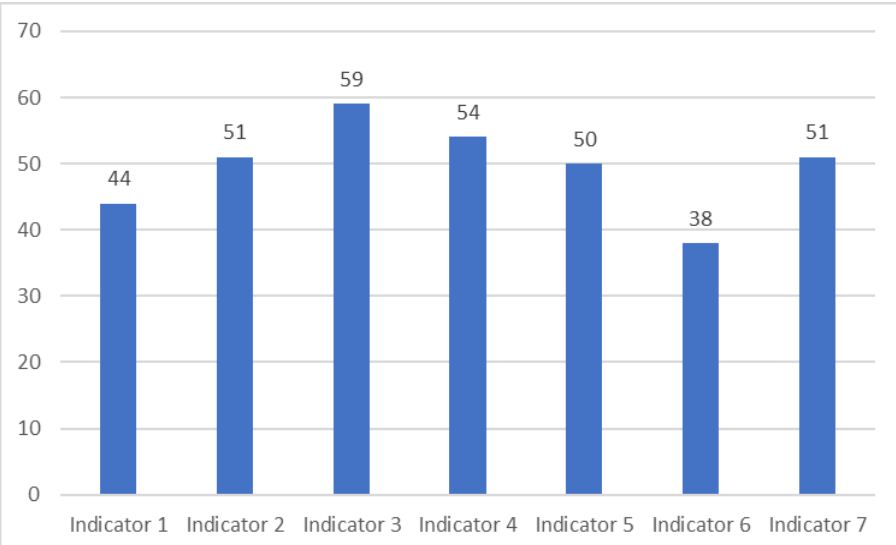

Figure 1. Histogram of Percentage of Results of Critical Thinking Ability

In table 2 and figure 1 shows the results of the critical thinking ability test on indicator 1 , that is identifying or formulating the problem by $44 \%$; indicator 2 is to identify or formulate criteria to determine an important answer of $51 \%$; indicator 3 that is building basic skills by $59 \%$; indicator 4 is concluding at 54\%; indicator 5 is inducing and considering the results of induction by $50 \%$; indicator 6 , which provides a further explanation of $38 \%$; indicator 7 is to formulate strategies and tactics by $51 \%$. The average percentage of achievement of critical thinking skills in grade X IPA students of SMA Negeri 7 Cirebon is less than 54\%, which is $49.57 \%$, this indicates that the category of critical thinking skills of students is very low.

In indicator 1 that is identifying or formulating a problem of $44 \%$ classified as very low category. The very low category obtained on the indicator is the students' curiosity is low and identifying the problem is not the development of ideas or ideas to be asked as a problem. This result is in line with 
research that shows some cases of students who are less clear at catching problems and less critical [13].

Indicator 2 is identifying or formulating criteria to determine the important answers by $51 \%$ classified as very low categories. On this indicator students do not provide relevant answers or in accordance with the questions asked. The indicator can determine the level of critical thinking of students in terms of suitability or relevance of the answers to the problems posed as a question of a problem and provide a solution or a way out of the statement used as an answer. Students with a qualified interpretation in understanding and expressing experience means having beliefs, rules and data in the learning process [14].

In indicator 3 namely building basic skills by $59 \%$ classified as low category. The low category obtained on these indicators cannot provide logical reasoning for an event or event so that the critical power that occurs in students is more likely to the ability of students to analyze the events seen and felt. Students who have competency analysis are more capable and able to identify the conclusions, actual, statements, questions, concepts, descriptions in expressing beliefs, judgments, experiences, reasons and information [14].

In indicator 4 , it is concluded that $54 \%$ is categorized as very low. The indicator emphasizes more on students' abilities in terms of providing reasons from a relevant source or in accordance with logical thinking, strengthening the source of information and providing solutions to a problem. Students will better understand if the factors that are the basis for capacity building, understanding focus and self-regulation are mastered [15,16]. Achieving goals must have a role helping students manage thoughts, emotions and behaviors for successful guidance and guiding learning experiences [17].

Indicator 5, which is inducing and considering the results of induction of $50 \%$, is categorized as very low. The indicator emphasizes the generality aspects or the reasoning ability of students to form conclusions in general through an event and explain precisely the cause of an event. This is in line with the research of ideal critical thinkers who usually want to know, are knowledgeable, trustworthy, open minded, flexible, honest, wise in making judgments and willing to reconsider [18].

The lowest critical thinking ability test results are found in indicator 6 , which provides a further explanation of $38 \%$. The low achievement of these indicators is that students find it difficult to define terms and relate an event to the material correctly and correctly. This is due to the lack of ability to interest reading literacy. Lack of ability to be interested in reading literacy allows students to be accustomed to using technological devices for things beyond learning. Critical thinking skills of low students are influenced by lack of activity, training, limited resources, limitation of environmental time in developing critical thinking skills [19].

In indicator 7 that is formulating strategies and tactics by $51 \%$ is classified as very low category. The achievement of these indicators is the low ability of students to interact with other people from environmental information and able to analyze information. Science with learning strategies to stimulate and facilitate students in exploring, building abilities that are very understandable when students are involved in active participation in learning and learning [20].

\section{CONCLUSION}

The results showed that the achievement of critical thinking skills in grade X IPA students of SMA Negeri 7 Cirebon was very low with an average achievement of critical thinking skills of students at $49.57 \%$. The results of this study provide an overview to the teacher and researchers about the condition of critical thinking skills in grade X IPA students of SMA Negeri 7 Cirebon.

Suggestions are the need to improve students' critical thinking skills by involving teachers to design and develop learning activities that can facilitate students to practice critical thinking so that students are more accustomed to critical thinking in everyday life. Teachers should involve students by giving assignments or critical thinking questions and train students to argue in discussion activities to be further improved.

\section{Acknowledgment}

The researcher thanked all those who helped in this study, especially the teachers and students of class X IPA at SMA Negeri 7 Cirebon.

\section{References}

[1] Gates, Bill. (1996). The Road Ahead. United Stated: Viking Penguin

[2] Trilling, B., \& Fadel, C. (2009). 21st Century Skills. Jossey-Bass, 256. https://doi.org/10.1145/1719292.1730970

[3] Morin, D., Thomas, J. D. E., \& Saadé, R. G. (2012). Activities and resources in online learning: From a critical thinking view. Proceedings of Informing Science and IT Education Conference.

[4] Duron, R., Limbach, B., \& Waugh, W. (2006). Critical Thinking Framework For Any Discipline. International Journal of Teaching and Learning in Higher Education, 17(2), 160-166. https://doi.org/10.1016/j.nepr.2006.09.004

[5] Bassham, G., Irwin, W., Nardone, H., \& Wallace, J. (2010). Critical Thinking: A Student's Introduction.

[6] Scriven, M., Paul, R., (1987). A statement by Michael Scriven and Richard Paul presented at "The Eighth Annual International Conference on Critical Thinking and Education Reform". From Defining Critical Thinking. 2009. Foundation for Critical Thinking, http://www.criticalthinking.org/aboutct/define_critical_ thinking.cfm. $(P D F)$ The use of critical thinking by Chinese students in Higher Education.. Available from: 
https://www.researchgate.net/publication/282671117_T he_use_of_critical_thinking_by_Chinese_students_in_ Higher_Education [accessed Sep 15 2018].

[7] Mapeala, R., \& Siew, N. M. (2015). The development and validation of a test of science critical thinking for fifth graders. $\quad$ SpringerPlus, $4(1), \quad 13$. https://doi.org/10.1186/s40064-015-1535-0

[8] Facione, P. a. (2011). Critical Thinking: What It Is and Why It Counts. Insight assessment. https://doi.org/ISBN 13: 978-1-891557-07-1

[9] Elisanti, E., \& Prayitno, B. A. (2018). The Profile of Critical Thinking Skill Students in XI Grade of Senior High School, 218(ICoMSE 2017), 205-209.

[10] Arikunto, Suharsimi. (2013). Prosedur Penelitian Suatu Pendekatan Praktik. Jakarta: PT. Bumi Aksara.

[11] Sugiyono. (2015). Metode Penelitian Pendidikan. Bandung: Alfabeta

[12] Kalelioğlu, F., \& Gülbahar, Y. (2014). The effect of instructional techniques on criticalthinking and critical thinkingdispositions in online discussion. Educational Technology and Society, 17(1), 248-258.

[13] Egege, S., \& Kutieleh, S. (2004). Critical thinking: Teaching foreign notions to foreign students. International Education Journal, 4(4), 75-85.

[14] Ricketts, J. C., \& Rudd, R. (2004). Critical Thinking Skills of FFA Leaders. Journal of Southern Agricultural Education Research, 54(1), 7-20.

[15] Jafarigohar, M. (2014). The Effect of Self-Regulation on Improving EFL Readers ' Ability to Make Within -
Text Inferences, 3(2), 263-286.

[16] Kamgar, N., \& Jadidi, E. (2016). Exploring the Relationship of Iranian EFL Learners $\square$ Critical Thinking and Self-regulation with their Reading Comprehension Ability. Procedia - Social and Behavioral Sciences, 232(April), 776-783. https://doi.org/10.1016/j.sbspro.2016.10.105

[17] Zumbrunn, S., Tadlock, J., \& Roberts, E. D. (2011). Encouraging Self-Regulated Learning in the Classroom: A Review of the Literature. Metropolitan Educational Research Consortium, (October 2011), 28. https://doi.org/10.1007/s10643-009-0305-4

[18] Facione, P. A. (1990). The California Critical Thinking Skills Test - College Level. Experimental Validation and Content Validity. California Academic Press, 114. https://doi.org/10.1.1.131.8583

[19] Smetanová, V., Drbalová, A., \& Vitáková, D. (2015). Implicit Theories of Critical Thinking in Teachers and Future Teachers. Procedia - Social and Behavioral Sciences, 171, 724-732. https://doi.org/10.1016/j.sbspro.2015.01.184

[20] Tiruneh, D. T., Verburgh, A., \& Elen, J. (2014). Effectiveness of Critical Thinking Instruction in Higher Education: A Systematic Review of Intervention Studies. Higher Education Studies, 4(1). https://doi.org/10.5539/hes.v4n1p1 